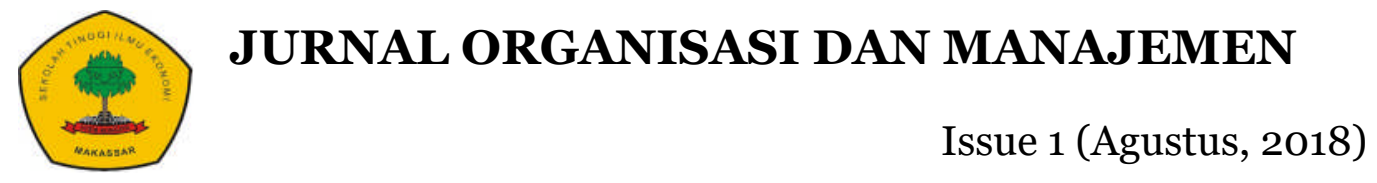

https://doi.org/10.31227/osf.io/qt8w7

\title{
Pengaruh profesionalisme dan komitmen organisasional terhadap kinerja guru
}

\author{
Ismail $^{1)}$ \& Herman Sjahruddin²) \\ mail19617@gmail.com
}

1) Mahasiswa Program Studi Manajemen pada Sekolah Tinggi Ilmu Ekonomi

Bongaya Makassar

2) Dosen Program Studi Manajemen pada Sekolah Tinggi Ilmu Ekonomi

Bongaya Makassar

\begin{abstract}
ABSTRAK
Penelitian ini bertujuan untuk mengetahui Pengaruh Profesionalisme Dan Komitmen Organisasi Terhadap Kinerja Guru SMK Kartika XX-1 Makassar. Pengumpulan data menggunakan data primer yang diperoleh dari kuesioner dengan menggunakan teknik Purposive sampling atau judgemental sampling. Populasinya adalah guru yang telah memperoleh sertifikat pendidik (sertifikasi guru) yang berjumlah 37 responden. Kuesioner penelitian telah melalui pengujian validitas dan reliabilitias, juga telah diuji asumsi klasik berupa asumsi normalitias. Heteroskedastisitas dan multikolinieritasnya. Metode analisis data menggunkan teknik regresi berganda melalui program SPSS ver. 23 memberikan bukti bahwa profesionalisme berpengaruh negative dan signifikan terhadap kinerja guru, komitmen organisasional berpengaruh negatif dan signifikan terhadap kinerja guru.
\end{abstract}

Kata kunci : $\quad$ Profesionalisme, komitmen organisasional, kinerja

\begin{abstract}
Regression analysis is constructed for capturing the effect of professionalism and organizational commitment on teachers performance of SMK Kartika XX-1 Makassar. The data collection used primary data through questionnaire by using purposive sampling or judgemental sampling technique. The population of this research was the teachers who are certified educators (Theacher Certification) which there were 37 respondents. The results of the questionnaire have tested for validity and reliability also have tested classical assumption of normalitas assumption. Heteroscedasticity and multicollinearity. The methods of data analysis using multiple regression techniques with SPSS 23 version. The results of this study proved that the professionalism have a negative and significant effect on teacher performance, organizational commitment is negative and significant on teacher performance
\end{abstract}

Keywords: Professionalism, organizational commitment, teachers

Authors : Ismail \& Herman Sjahruddin. Issue 1 (Agustus, 2018); 99 112 


\section{JURNAL ORGANISASI DAN MANAJEMEN}

Issue 1 (Agustus, 2018)

https://doi.org/10.31227/osf.io/qt8w7

performance

\section{Latar Belakang}

Perubahan paradigma pengajaran pada dunia pendidikan menengah dan atas dari cara belajar siswa aktif (CBSA) ke study learning centre (SLC) menuntut dilakukannya peningkatan kinerja guru secara maksimal. Pencapaian kinerja guru secara maksimal dapat dilakukan melalui peningkatan profesionalisme guru dalam bekerja atau dalam melaksanakan tugas dan kewajibannya (Dhanawaty, 2017).

Kinerja adalah suatu hasil kerja yang dicapai seorang dalam melaksanakan tugas-tugas yang dibebankan kepadanya yang didasarkan atas kecakapan, pengalaman dan kesungguhan serta waktu. Dengan kata lain bahwa kinerja adalah hasil kerja yang dicapai oleh seseorang dalam melaksanakan tugas yang diberikan kepadanya sesuai dengan kriteria yang ditetapkan (Sutiadi, 2003:6; dalam Brahmasari, dan Suprayetno, 2009). Keberhasilan dan kinerja seseorang banyak ditentukan oleh tingkat kompetensi, profesionalisme dan juga komitmen terhadap bidang yang ditekuninya (Sri Trisnaningsih, 2001; dalam Tranggono dan Kartika, 2008).

Penciptaan pengaruh antara variabel dalam penelitian ini merujuk pada teori kinerja/performance (P) yang dikemukakan oleh (Greenberg dan Baron, 1980; dalam Indarjanti dan Bodroastuti, 2012), bahwa kinerja merupakan hasil dari kemampuan/ability (A) dikalikan dengan usaha/effort (E) dikalikan dengan dukungan/support (S), P= A x E x S. Kinerja akan berkurang apabila salah satu faktor dikurangi atau tidak ada. Kemampuan adalah kemampuan alami yang melibatkan bakat dan minat yang tepat untuk pekerjaan yang diberikan. Usaha adalah suatu praktik yang diperlukan untuk kegiatan organisasi yang aman dan efisien. Dukungan organisasi adalah dukungan yang diterima dari organisasinya berupa pelatihan, peralatan, harapan-harapan dan tim kerja yang produktif (Mathis dan Jackson, 2001:83). Teori tersebut menjelaskan bahwa penciptaan kinerja individu disebabkan karena adanya kemampuan (ability) yang dalam penelitian ini ditunjukan melalui komitmen organisasional guru dan usaha (effort) yang dalam penelitian ini ditunjukan dengan profesionalisme yang kemudian dengan adanya dukungan (support) dari pihak manajemen sekolah sehingga guru mampu menghasilkan kinerja yang tinggi.

Dalam bidang pendidikan, tuntutan terhadap kemampuan memberikan layanan yang lebih profesional khususnya dalam proses pembelajaran serta bimbingan bagi peserta didik menjadi keharusan untuk dilaksanakan. Untuk mencapai tujuan pendidikan nasional yakni mencerdaskan kehidupan bangsa dan mengembangkan manusia Indonesia seutuhnya, sangat dibutuhkan peran pendidik yang profesional. UndangUndang Sistem Pendidikan Nasional (UU Nomor 20 Tahun 2003)

Halaman 100

Authors : Ismail \& Herman Sjahruddin. Issue 1 (Agustus, 2018); 99 112 


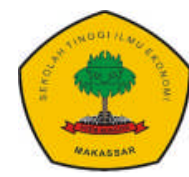

\section{JURNAL ORGANISASI DAN MANAJEMEN}

Issue 1 (Agustus, 2018)

https://doi.org/10.31227/osf.io/qt8w7

dikemukakan bahwa jabatan guru sebagai pendidik merupakan jabatan profesional (Astuti, 2012). Profesionalisme guru merupakan suatu situasi atau peristiwa yang terbuka dan penuh kebebasan bagi guru untuk mengembangkan pembelajaran secara efektif dalam suatu standard yang tinggi dengan rasa tanggung jawab dan mengarahkan diri sendiri dan secara terus menerus mengembangkan diri sebagai guru. Dalam keadaan ini profesionalisme utamanya ditandai oleh adanya kebebasan bagi guru guna menentukan pendekatan, strategi atau langkah-langkah yang dianggap tepat untuk mewujudkan suatu proses pembelajaran yang lebih berhasil guna. (Hall dan Schulz, 2003; dalam Astuti, 2012).

Seseorang dikatakan profesional jika memenuhi tiga kriteria, yaitu mempunyai keahlian untuk melaksanakan tugas sesuai dengan bidangnya, melaksanakan suatu tugas atau profesi dengan menetapkan standar baku di bidang profesi yang bersangkutan dan menjalankan tugas profesinya dengan mematuhi etika profesi yang telah ditetapkan. Profesi merupakan jenis pekerjaan yang memenuhi beberapa kriteria, sedangkan profesionalisme merupakan suatu atribut individual yang penting tanpa melihat apakah suatu pekerjaan merupakan suatu profesi atau tidak (Fujianti, 2012). Kompetensi professional merupakan cerminan dari profesionalisme guru berpengaruh langsung posisitif signifikan terhadap kinerja guru (Sumarsih, 2017). Hasil tersebut berbeda dengan temuan peneliti lainya, bahwa profesionalisme tidak signfikan pengaruhnya terhadap kinerja auditor (Ramadika dkk., 2014).

Temuan lapangan menunjukan bahwa guru yang bekerja pada Sekolah Menengah Kejuruan (SMK) Kartika XX-1 Makassar bahwa profesionalisme guru yang ditunjukan dengan pembuatan Rencana Program Pembelajaran (RPP) yang belum sesuai dengan standar yang seharusnya dan masi terbatasnya guru yang memperoleh sertikat pendidik (Sertifikasi Guru), masi terdapatnya guru yang ketika melaksanakan tugasnya yang belum mampu memisahkan urusan keluarga dengan urusan pekerjaan, sehingga berdasarkan fakta lapang tersebut maka dapat disimpulkan bahwa guru profesionalisme pada Sekolah Menengah Kejuruan (SMK) Kartika XX-1 Makassar masi tergolong rendah.

Selain faktor profesionalisme terdapat pula faktor lain yang mempengaruhi kinerja yaitu komitmen organisasional (Luthan, 1995; dalam Devi, 2009). Komitmen organisasional merupakan dorongan dalam diri individu untuk berbuat sesuatu agar dapat menunjang keberhasilan organisasi dengan lebih mengutamakan kepentingan organisasi. (Winner, 1982; dalam Tranggono, dan Kartika, 2008). Bukti penelitian terdahulu menujukan bahwa komitmen organisasional berpengaruh positif signifikan terhadap kinerja auditor (Alfianto, dan Suryandari, 2015). Sedangkan penelitian lainnya, komitmen organisasional tidak mempunyai pengaruh positif dan signifikan terhadap kinerja dosen. (Nongkeng, 2012).

Halaman 101

Authors : Ismail \& Herman Sjahruddin. Issue 1 (Agustus, 2018); 99 112 
Issue 1 (Agustus, 2018)

https://doi.org/10.31227/osf.io/qt8w7

Fakta lapangan menunjukkan bahwa umumnya guru yang bekerja pada Sekolah Menengah Kejuruan (SMK) Kartika XX-1 Makassar di dominasi oleh guru muda (junior) sementara sekolah tersebut tergolong tua atau sudah lama didirikan, hal ini membuktikan bahwa kecenderungan guru untuk beralih (pindah) ke sekolah lain sehingga dengan kondisi tersebut dapat dinyatakan bahwa guru memiliki loyalitas (komitmen) yang rendah.

\section{Tinjauan Teoritis}

\section{Profesionalisme}

Profesional berasal dari kata sifat yang berarti pencaharian dan sebagai kata benda yang berarti orang yang mempunyai keahlian seperti guru, dokter, hakim, dan sebagainya. Dengan kata lain pekerjaan yang bersifat profesional adalah pekerjaan yang hanya dapat dilakukan oleh mereka yang khusus dipersiapkan untuk itu dan bukan pekerjaan yang dilakukan oleh mereka yang karena tidak dapat memperoleh pekerjaan lain. (Moh. Uzer Usman, 2010; dalam Zakaria, 2016). Profeslonalisme dilihat dari pengertian bahasanya, bisa mempunyai beberapa makna. Pertama. profesionalisme berarti suatu keahlian, mempunyai kualifikasi tertentu, berpengalaman sesuai dengan bidang keahliannya. Kedua, pengertian profesionalisme merujuk pada suatu standar pekerjaan yaitu prinsip-prinsip moral dan etika profesi, Ketiga, profesional berarti moral. (Fujianti, 2012; Sari \& Sjahruddin, 2018).

\section{Komitmen Organisasional}

Komitmen organisasional adalah perasaan, sikap dan perilaku individu dalam mengidentifikasi dirinya sebagai bagian dari organisasi, terlibat dalam proses kegiatan organisasi dan loyal terhadap organisasi dalam mencapai tujuan organisasi (Wibowo,2014:428). Definisi lainnya menjelaskan bahwa komitmen organisasi (organizational commitment) merupakan suatu keadaan dimana seorang karyawan memihak terhadap tujuan-tujuan organisasi serta memiliki keinginan untuk mempertahankan keanggotaannya dalam organisasi tersebut. (Robbins dan Judge, 2008; dalam Puspitawati, 2013).

\section{Kinerja guru}

Kinerja adalah suatu hasil kerja yang dicapai seorang dalam melaksanakan tugas-tugas yang dibebankan kepadanya yang didasarkan atas kecakapan, pengalaman dan kesungguhan serta waktu. Dengan kata lain bahwa kinerja adalah hasil kerja yang dicapai oleh seseorang dalam melaksanakan tugas yang diberikan kepadanya sesuai dengan kriteria yang ditetapkan (Sutiadi, 2003:6; dalam Brahmasari, dan Suprayetno, 2009)

\section{Metode Penelitian}

Penelitian ini menggunakan pendekatan kuantitatif dengan explanatory survey yaitu penelitian yang mengambil sampel dari suatu populasi yang di teliti dan menjelaskan hubungan atau kausalitas antara variabel-variabel yang akan melalui pengujian hipotesis. Penelitian ini menggunakan pendekatan 
https://doi.org/10.31227/osf.io/qt8w7

kuantitatif yang datanya berwujud pada bilangan (angka-angka) dan pembuktian hipotesis yang dilakukan menggunakan analisis statistik (Sugiyono, 2013:13; dalam Yulianti., dkk, 2017).

\section{Hasil Penelitian}

\section{Hasil Uji Instrumen}

Uji instrument penelitian digunakan untuk menguji tingkat keakuratan data dalam pengujian hipotesis. Sehingga dalam uji instrument diterapkan uji validitas dan reliabilitas. Uji validitas dilakukan untuk menguji validasi data yang merupakan suatu ukuran yang menujukkan tingkat keandalan atau kesahilan alat ukur. Validasi data dalam suatu penelitian dilakukan dengan teknis analisis item, yaitu dengan cara mengkolerasi skor tiap-tiap item pernyataan dengan total skor untuk masing-masing variabel. Suatu indikator dikatakan valid jika nilai person correlation $(r=>0.30)$ dan tingkat signifikansinya $(\alpha=<0.05)$. Uji reliabilitas dipakai untuk mengukur keandalan suatu instrument yang digunakan untuk memprediksi, pada penelitian ini digunakan koefisien standar Alpha Croncbach $=>0,60$, untuk itu ditunjukkan pada table berikut :

Tabel 1. Validitas dan reliabilitas

\begin{tabular}{|c|c|c|c|}
\hline Variabel & Indikator & Corellation & $\begin{array}{c}\text { Cronbach's } \\
\text { Alpha }\end{array}$ \\
\hline \multirow{10}{*}{ Profesionalisme } & $\mathrm{X}_{111}$ & 0.960 & \multirow{9}{*}{0.644} \\
\hline & $\mathrm{X}_{112}$ & 0.962 & \\
\hline & $X_{121}$ & 0.759 & \\
\hline & $\mathrm{X}_{122}$ & 0.926 & \\
\hline & $\mathrm{X}_{131}$ & 0.758 & \\
\hline & $\mathrm{X}_{132}$ & 0.750 & \\
\hline & $\mathrm{X}_{133}$ & 0.703 & \\
\hline & $\mathrm{X}_{141}$ & 0.562 & \\
\hline & $\mathrm{X}_{142}$ & 0.927 & \\
\hline & $\mathrm{X}_{143}$ & 0.927 & \multirow{6}{*}{0.769} \\
\hline \multirow{5}{*}{$\begin{array}{c}\text { Komitmen } \\
\text { Organisasional }\end{array}$} & $\mathrm{X}_{211}$ & 0.960 & \\
\hline & $\mathrm{X}_{212}$ & 0.937 & \\
\hline & $\mathrm{X}_{221}$ & 0.870 & \\
\hline & $\mathrm{X}_{222}$ & 0.951 & \\
\hline & $\mathrm{X}_{223}$ & 0.480 & \\
\hline \multirow{9}{*}{ Kinerja guru } & $\mathrm{Y}_{111}$ & 0.565 & \multirow{9}{*}{0.787} \\
\hline & $\mathrm{Y}_{112}$ & 0.710 & \\
\hline & $Y_{113}$ & 0.703 & \\
\hline & $\mathrm{Y}_{121}$ & 0.472 & \\
\hline & $\mathrm{Y}_{122}$ & 0.917 & \\
\hline & $\mathrm{Y}_{123}$ & 0.853 & \\
\hline & $Y_{131}$ & 0.686 & \\
\hline & $Y_{132}$ & 0.693 & \\
\hline & $\mathrm{Y}_{133}$ & 0.519 & \\
\hline
\end{tabular}

Berdasarkan pada tabel 1 menujukkan bahwa semua indikator dari masing-masing variabel terbuksi memenuhi pengujian keabsahan dan kehandalan data. 


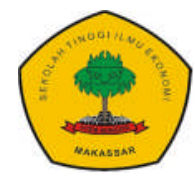

JURNAL ORGANISASI DAN MANAJEMEN

Issue 1 (Agustus, 2018)

https://doi.org/10.31227/osf.io/qt8w7

\section{Hasil Uji Asumsi Klasik}

Sebuah model regresi dikatakan baik sebagai model empirik jika telah memenuhi serangkaian pengujian asumsi klasik. Uji asumsi klasik dalam penelitian ini yaitu :

a. Uji Normalitas

Uji normalitas bertujuan untuk mendeteksi untuk mengetahui model terebut memiliki distribusi normal. Dapat dilakukan dengan menggunakan analisis Kolmogorov-Smirnov (K-S). Jika nilai signifikan uji Kolmogorov-Smimov $>0.05$ berarti data terdistribusi normal.

Tabel 2. Hasil Uji Normalitas Data

One-Sample Kolmogorov-Smirnov Test

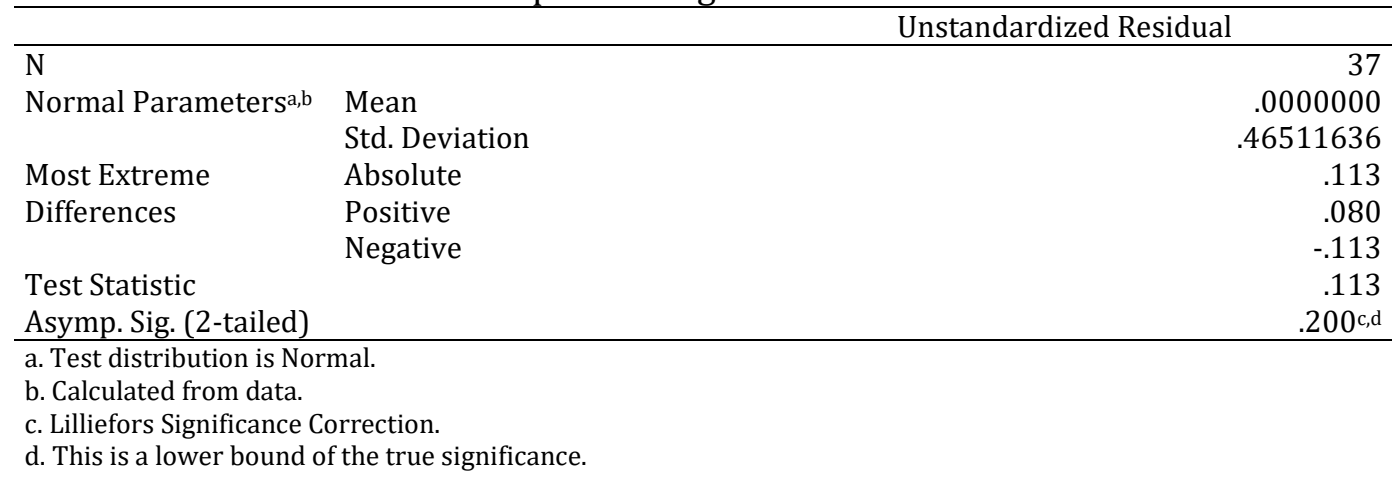

Berdasarkan tabel 2, menjelaskan bahwa nilai K-S yaitu $0.113>0.05$ serta nilai signifikansi yaitu $0.200>0.05$, maka dapat disimpulkan bahwa data dalam penelitian ini terdistribusi normal.

b. Uji Multikolinearitas

Uji multikolinearitas bertujuan untuk menguji apakah model regresi ditemukan adanya korelasi antara variabel bebas (Independent). Dasar pengambilan keputusan dalam uji multikolinearitas yaitu dengan melihat Tolerance Value dan Variance Inflation Factor (VIF). Syahruddin, dkk (2017:41). Dimana bahwa bila VIF $<10$ atau nilai tolerance $>0.10$ maka tidak terjadi multikolinearitas.

Tabel 3.Hasil Uji Multikolinearitas

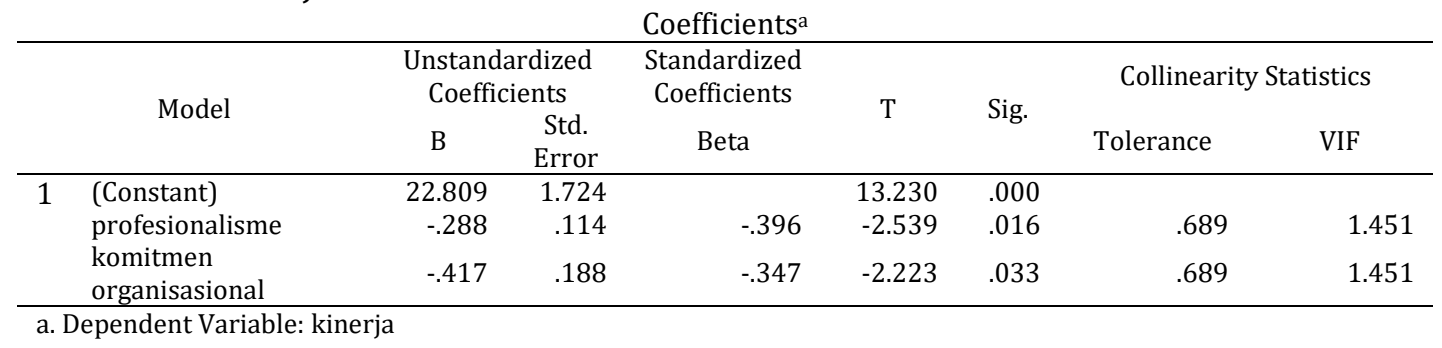

Variabel profesionalisme dengan nilai tolerance yaitu $0.689>0.10$ dan nilai VIF $1.451<10.00$, sedangkan untuk variabel komitmen organisasi

Halaman 104

Authors : Ismail \& Herman Sjahruddin. Issue 1 (Agustus, 2018); 99 112 


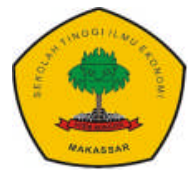

Issue 1 (Agustus, 2018)

https://doi.org/10.31227/osf.io/qt8w7

dengan nilai tolerance $0.689>0.10$ dan nilai VIF $1.451>10.00$. Maka dapat di simpulkan bahwa model regresi linear tidak terjadi multikolinearitas.

c. Uji Heteroskedastisitas

Tujuan dari uji heteroskedastisitas bertujuan untuk menguji apakah dalam model regresi terjadi ketidaksamaan variance dari residual satu pengamatan ke pengamatan yang lain. Model regresi yang baik adalah homokedastisitas. Apabila koefisien parameter beta > 0.05 maka tidak ada masalah heteroskedastisitas. Syahruddin, dkk (2017:41).

Tabel 4. Uji Heteroskedastisitas

\begin{tabular}{|c|c|c|c|c|c|}
\hline \multicolumn{6}{|c|}{ Coefficients ${ }^{\mathrm{a}}$} \\
\hline \multirow[b]{2}{*}{ Model } & \multicolumn{2}{|c|}{$\begin{array}{c}\text { Unstandardized } \\
\text { Coefficients }\end{array}$} & $\begin{array}{c}\text { Standardized } \\
\text { Coefficients }\end{array}$ & \multirow[b]{2}{*}{$\mathrm{t}$} & \multirow[b]{2}{*}{ Sig. } \\
\hline & $\mathrm{B}$ & Std. Error & Beta & & \\
\hline $1 \quad$ (Constant) & 1.146 & 1.139 & & 1.007 & .321 \\
\hline profesionalisme & -.086 & .075 & -.232 & -1.146 & .260 \\
\hline komitmen organisasi & .078 & .124 & .128 & .630 & .533 \\
\hline
\end{tabular}

a. Dependent Variable: HETERO

Berdasarkan hasil pada tabel 4 menujukkan bahwa nilai signifikan pada pengujian heteroskedastisitas untuk variabel profesionalisme yaitu $0.260>0.05$, untuk variabel komitmen organisasi $0.533>0.05$. Dapat disimpulkan bahwa model regresi dalam penelitian ini tidak terjadi heteroskedastisitas.

\section{Analisis Regresi Ganda}

Teknik analisis data yang digunakan untuk menentukan sejauh mana kesamaan antara hasil yang diperoleh dari suatu sampel dengan hasil yang akan didapat pada populasi secara keseluruhan. Jadi statistik inferensi membantu peneliti untuk mencari tahu apakah hasil yang diperoleh dari suatu sampel dapat digeneralisasi pada populasi. Penguji hipotesis dilakukan dengan persamaan regresi berganda, dengan rumus :

$$
\begin{array}{ll}
\mathrm{Y}=\alpha+\beta_{1} \mathrm{X}_{1}+\beta_{2} \mathrm{X}_{2}+\mathrm{e} \\
\text { Dimana } & \\
\mathrm{Y} & =\text { Kinerja karyawan. } \\
\mathrm{X}_{1} & =\text { Profesionalisme } \\
\mathrm{X}_{2} & =\text { Komitmen Organisasional } \\
\alpha & =\text { Konstanta } \\
\beta_{1} & =\text { Koefisien regresi untuk Profesionalisme } \\
\beta_{2} & =\text { Koefisien regresi untuk Komitmen Organisasional } \\
\mathrm{e} & =\text { Standar Error }
\end{array}
$$

Hasil pengujian regresi ganda dalam penelitian ini dapat dilihat pada tabel 5 dibawah ini :

Tabel 5. Hasil Uji Regresi Ganda

\begin{tabular}{lcccc}
\multicolumn{5}{c}{ Coefficients $^{\mathrm{a}}$} \\
Model & $\begin{array}{c}\text { Unstandardized } \\
\text { Coefficients }\end{array}$ & $\begin{array}{c}\text { Standardized } \\
\text { Coefficients }\end{array}$ & t & Sig.
\end{tabular}

Authors : Ismail \& Herman Sjahruddin. Issue 1 (Agustus, 2018); 99 112 


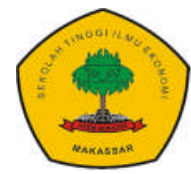

\section{JURNAL ORGANISASI DAN MANAJEMEN}

Issue 1 (Agustus, 2018)

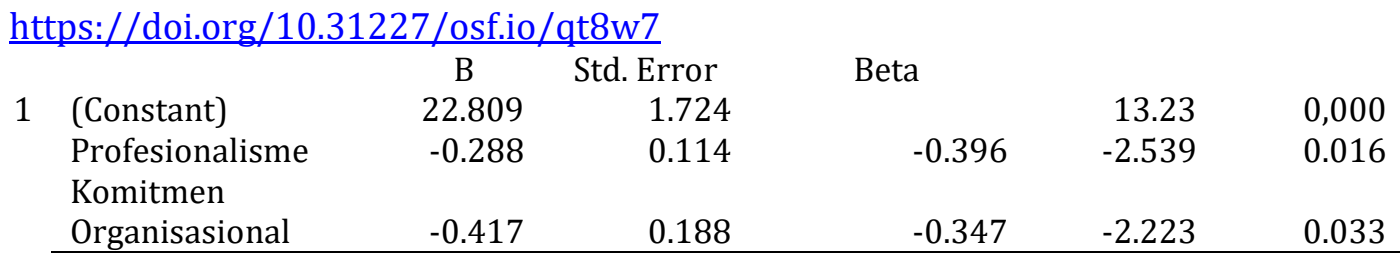

a. Dependent Variable: kinerja

$$
\begin{aligned}
& \mathrm{Y}=\mathrm{a}+\mathrm{b}_{1} \mathrm{X}_{1}+\mathrm{b}_{2} \mathrm{X}_{2}+\mathrm{e} \\
& \mathrm{Y}=22.809-0.288 \mathrm{X}_{1}-0.417 \mathrm{X}_{2}+\mathrm{e}
\end{aligned}
$$

Hasil dari persamaan regresi tersebut menujukkan arah variabel bebas (Independen) yaitu profesionalisme terhadap variabel terikat (Dependen) yaitu kinerja. Koefisien X1 bernilai $(-0.288)$ dengan nilai sig $0.016<0.05$ sehingga pengaruhnya negatif dan signifikan terhadap kinerja.

Hasil dari persamaan regresi tersebut menujukkan arah variabel bebas (Independen) yaitu komitmen organisasi terhadap variabel terikat (Dependen) yaitu kinerja. Koefisien X2 bernilai ( -0.417$)$ dengan nilai sig $0.033<0.05$ sehingga pengaruhnya negatif dan signifikan terhadap kinerja.

1. Uji Hipotesis

Uji hipotesis merupakan suatu pengujian untuk membuktikan adanya hubungan antara variabel dalam penelitian ini. Uji hipotesis bertujuan untuk mengetahui jawaban sementara terhadap masalah masih praduga karena masih harus dibuktikan kebenarannya sesuai dengan pendapat sementara yang diutarakan peneliti.

a. Uji F (Model)

Uji model dalam penelitian ini digunakan untuk menguji apakah model yang disusun peneliti dapat diterima dan dilanjutkan ke analisis data selanjutnya. Data pengambilan keputusan dalam uji model ini yaitu F-hitung > F-tabel, maka model tersebut diterima. Hasil uji model dapat dilihat pada tabel 6 di bawah ini :

Tabel 6. Uji F

\begin{tabular}{|c|c|c|c|c|c|c|}
\hline & Model & Sum of Squares & Df & Mean Square & $\mathrm{F}$ & Sig. \\
\hline \multirow[t]{3}{*}{1} & Regression & 5.876 & 2 & 2.938 & 12.827 & $.000^{\mathrm{b}}$ \\
\hline & Residual & 7.788 & 34 & .229 & & \\
\hline & Total & 13.664 & 36 & & & \\
\hline
\end{tabular}

ANOVA $^{a}$

a. Dependent Variable: kinerja

b. Predictors: (Constant), komitmen organisasi, profesionalisme

Berdasarkan pada tabel 6 menujukkan bahwa hasil pengujian model diperoleh nilai F-hitung ( 12.827) > F-tabel (3.276), sehingga hasil tersebut menujukkan bahwa data yang digunakan dalam penelitian ini dipandang sesuai (memenuhi kriteria model) bahwa nilai F-hitung > F-tabel.

b. Uji Parsial (Uji t)

Halaman 106

Authors : Ismail \& Herman Sjahruddin. Issue 1 (Agustus, 2018); 99 112 


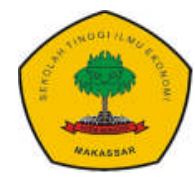

Issue 1 (Agustus, 2018)

https://doi.org/10.31227/osf.io/qt8w7

Pengujian ini dilakukan untuk mengetahui pengaruh signifikan variabel profesionalisme dan komitmen organisasi terhadap kinerja guru secara parsial dan menjawab hipotesis yang telah disusun oleh peneliti dalam penelitian ini. Dasar pengambilan keputusan dalam uji ini yaitu :

a) Jika t-hitung $>$ t-tabel dan sig $>0.05$, HO ditolak dan Ha diterima maka hipotesis diterima.

b) Jika t-tabel $<$ t-hitung dan sig $>0.05$, HO diterima dan Ha ditolak maka hipotesis ditolak.

Hasil pengujian $\mathrm{t}$ dapat dilihat pada tabel 7 dibawah ini :

Tabel 7. Uji - $\mathrm{t}$

\begin{tabular}{|c|c|c|c|c|c|}
\hline \multicolumn{6}{|c|}{ Coefficients $^{\mathrm{a}}$} \\
\hline \multirow[b]{2}{*}{ Model } & \multicolumn{2}{|c|}{$\begin{array}{l}\text { Unstandardized } \\
\text { Coefficients }\end{array}$} & \multirow{2}{*}{$\begin{array}{l}\text { Standardized } \\
\text { Coefficients } \\
\text { Beta }\end{array}$} & \multirow[b]{2}{*}{$\mathrm{t}$} & \multirow[b]{2}{*}{ Sig. } \\
\hline & $\mathrm{B}$ & Std. Error & & & \\
\hline 1 (Constant) & 22.809 & 1.724 & & 13.230 & .000 \\
\hline Profesionalisme & -.288 & .114 & -.396 & -2.539 & .016 \\
\hline $\begin{array}{l}\text { Komitmen } \\
\text { Organisasional }\end{array}$ & -.417 & .188 & -.347 & -2.223 & .033 \\
\hline
\end{tabular}

a. Dependent Variable: Kinerja

Pada pengujian tabel 7 variabel profesionalisme menujukkan thitung $(-2.539)<$ t-tabel $(2.028)$ dan nilai signifikan sebesar $0.016<0.05$ maka $\mathrm{H}_{\mathrm{a}}$ ditolak dan $\mathrm{H}_{0}$ diterima. Dapat dikatakan bahwa profesionalisme secara parsial berpengaruh negatif dan signifikan terhadap kinerja guru pada SMK Kartika XX-1 Makassar, sehingga hipotesis dalam penelitian ini ditolak. Variabel komitmen organisasi menujukkan t-hitung $(-2.223)<\mathrm{t}$ tabel (2.028) dan nilai signifikan sebesar $0.033<0.05$ maka $\mathrm{H}_{\mathrm{a}}$ ditolak dan $\mathrm{H}_{\mathrm{o}}$ diterima. Dapat dikatakan bahwa komitmen organisasi secara parsial berpengaruh negatif dan signifikan terhadap kinerja guru pada SMK Kartika XX-1 Makassar, sehingga hipotesis dalam penelitian ini ditolak.

c. Analisis koefisien korelasi dan determinasi $\left(\mathrm{R}^{2}\right)$

Koefisien determinasi ini berfungsi untuk mengetahui persentase besarnya pengaruh profesionalisme dan komitmen organisasi terhadap kinerja guru. Hasil uji determinasi dalam penelitian ini dapat dilihat pada tabel 8 yaitu :

Tabel 8. Uji Determinasi $\left(\mathrm{R}^{2}\right)$

Model Summary ${ }^{b}$

\begin{tabular}{llrrr}
\hline Model & R & R Square & Adjusted R Square & Std. Error of the Estimate \\
\hline 1 & $.656^{\mathrm{a}}$ & .430 & .397 & .47860 \\
\hline
\end{tabular}

a. Predictors: (Constant), Komitmen Organisasional, Profesionalisme

b. Dependent Variable: Kinerja

$\mathrm{Kd}=\mathrm{r}^{2} \times 100 \%$

$\mathrm{Kd}=0.430 \times 100 \%$

Keterangan :

$\mathrm{Kd} \quad=$ Koefisien determinasi

Halaman 107

Authors : Ismail \& Herman Sjahruddin. Issue 1 (Agustus, 2018); 99 112 


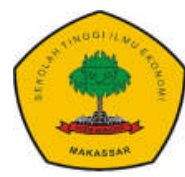

\section{JURNAL ORGANISASI DAN MANAJEMEN}

Issue 1 (Agustus, 2018)

https://doi.org/10.31227/osf.io/qt8w7

$\mathrm{r}=$ Koefisien korelasi yang dikuadratkan

Berdasarkan tabel 8 di atas, dapat disimpulkan bahwa R-square sebesar 0.430 yang diperoleh dari

a) Kontribusi X1 sebesar 23,30\% $=-0,589 \times 0,396$

b) Kontribusi X2 sebesar $19,70 \%=-0,567$ X 0,347

Sehingga pengaruh variabel bebas (Independen) yaitu profesionalisme dan komitmen organisasi terhadap variabel terikat (Dependen) yaitu kinerja guru sebesar $43 \%$, sedangkan sisanya sebesar 57\% dipengaruhi oleh faktor lain yang tidak dijelaskan dalam penelitian ini.

\section{Interpretasi Hasil Penelitian}

1) Pengaruh profesionalisme terhadap kinerja guru

Pengaruh profesionalisme terhadap kinerja guru dapat dibuktikan dengan nilai koefisien yang tidak terstandarisasi (Unstandardized Coefficients) sebesar -0,288 dan nilai koefisien terstandirdisasi (Standardized Coefficients) sebesar -0,396. Nilai koefisien tersebut bertanda negatif yang menjelaskan bahwa semakin rendah profesionalisme guru, maka semakin tinggi kinerja guru.

Hasil tersebut didukung dengan nilai t-hitung sebesar $-2.539<\mathrm{t}$-tabel sebesar 2.028 dengan nilai signifikansi p-value sebesar $0.016<0.05$. Hasil tersebut membuktikan bahwa profesionalisme guru berpengaruh negatif dan signifikan terhadap kinerja guru SMK Kartika XX-1 Makassar yang menjelaskan bahwa rendahnya profesionalisme guru yang disebabkan karena rendahnya kemampuan kepribadian yang kurang stabil dan sikap dewasa tidak mampu di tampilkan secara terus menerus didepan peserta didik yang merupakan penjabaran dari indikator kemampuan kepribadian, ternyata dalam pelaksanaannya terbukti mampu menigkatkan kemampuan guru yang tinggi dalam proses penyusunan program kegiatan rencana pelaksanaan pembelajaran (RPP) dan pengembangkan silabus sebagai cerminan dari kinerja guru.

Fakta lainya, kondisi tersebut diakibatkan karena kemampuan guru yang kurang komunikasi dan bergaul secara efektif dengan peserta didik, sesama pendidik, tenaga kependidikan, orang tua peserta didik, dan masyarakat sekitar. Sehingga berdampak terhadap tingginya kualitas penilaian pembelajaran guru dalam mengetahui tercapai atau tidaknya tujuan pembelajaran dan juga proses pembelajaran yang telah dilakukan.

Hasil penelitian ini menolak temuan Sumarsih (2017) professional merupakan cerminan dari profesionalisme guru berpengaruh langsung posisitif signifikan terhadap kinerja guru. Kemudian temuan Ramadika dkk (2014) bahwa profesionalisme tidak signfikan pengaruhnya terhadap kinerja auditor.

2) Pengaruh komitmen organisasional terhadap kinerja guru

Komitmen organisasional adalah perasaan, sikap dan perilaku individu dalam mengidentifikasi dirinya sebagai bagian dari organisasi, terlibat dalam proses kegiatan organisasi dan loyal terhadap organisasi dalam 


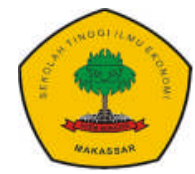

JURNAL ORGANISASI DAN MANAJEMEN

Issue 1 (Agustus, 2018)

https://doi.org/10.31227/osf.io/qt8w7

mencapai tujuan organisasi (Wibowo,2014:428). Pengaruh komitmen organisasional terhadap kinerja guru dapat dibuktikan dengan nilai keofisien yang tidak terstandirdisasi (Unstandardized Coefficients) sebesar 0.417 dan nilai koefisien terstandirdisasi (Standardized Coefficients) sebesar -0,347. Nilai Koefisien tersebut bertanda negative yang menjelaskan bahwa semakin rendah komitmen organisasional guru, maka semakin kurang kinerja guru.

Hasil tersebut didukung dengan nilai t-hitung sebesar $-2.223<\mathrm{t}$-tabel sebesar 2.028 dengan nilai signifikansi, p-value sebesar $0.033<0.05$. Hasil tersebut membuktikan bahwa komitmen organisasional guru berpengaruh negatif dan signifikan terhadap kinerja guru SMK Kartika XX-1 Makassar,sehingga hipotesis yang diajuakan ternyata ditolak.

Faktor penyebab negative dan signifikannya pengaruh komitmen organisasional terhadap kinerja guru diakibatkan karena rendahnya keinginan untuk tetap bertahan diorganisasi karena guru tersebut tidak takut kehilangan keuntungan finansial dan tidak memperoleh pekerjaan di tempat lain yang merupakan penjabaran dari indikator komitmen berkelanjutan, ternyata dalam pelaksanaannya terbukti guru mampu meningkatkan pencapaian prestasi anak siswa (i) sebagai cerminan dari kinerja guru.

Faktor lainnya disebabkan karena mudahnya guru berpindah dari sekolah satu kesekolah lain merupakan penyabaran dari indikator komitmen berkelanjutan, sehingga berdampak terhadap tingginya perhatian guru untuk menguasai bahan yang akan diajarkan. Hasil penelitian ini menolak temuan Alfianto, dan Suryandari (2015) bahwa komitmen organisasional berpengaruh positif signifikan terhadap kinerja auditor. Kemudian menolak temuan Nongkeng (2012) bahwa komitmen organisasional tidak mempunyai pengaruh positif dan signifikan terhadap kinerja dosen.

3) Pengaruh variabel yang dominan (komitmen organisasional) terhadap kinerja guru

Pengujian variabel yang dominan dilakukan dengan membandingkan nilai t-statistik atau t-hitung antara profesionalisme sebesar -2.539 dengan thitung pada variabel komitmen organisasional sebesar -2.223. Sehingga dengan demikian variabel yang dominan mempengaruhi kinerja guru adalah komitmen organisasional karena nilai t-hitung komitmen organisasional < dibandingkan t-hitung profesionalisme. Sehingga hipotesis $\left(\mathrm{H}_{3}\right)$ diajukan bahwa komitmen organisasional merupakan variabel yang dominan berpengaruh terhadap kinera guru pada SMK Kartika XX-1 Makasssar, terbukti diterima.

Hasil ini disebabkan karena komitmen organisasional yang berdasarkan fakta lapangan yang ada, menujukkan bahwa kurangnya perasaan, sikap dan perilaku guru dalam mengidentifikasi dirinya sebagai bagian dari organisasi, tidak terlibatnya dalam proses kegiatan organisasi dan kurang loyal terhadap organisasi dalam mencapai tujuan organisasi.

Authors : Ismail \& Herman Sjahruddin. Issue 1 (Agustus, 2018); 99 112 


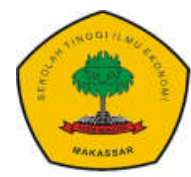

JURNAL ORGANISASI DAN MANAJEMEN

Issue 1 (Agustus, 2018)

https://doi.org/10.31227/osf.io/qt8w7

\section{Kesimpulan dan Saran}

Variabel profesionalisme $\left(\mathrm{X}_{1}\right)$ berpengaruh negative dan signifikan terhadap kinerja guru (Y) pada SMK Kartika XX-1 Makassar. Hal ini ditunjukkan pada tabel 4.19 nilai profesionalisme pada kolom $t_{\text {hitung }}$ sebesar -2.539 dimana nilai ini lebih kecil dari nilai $t_{\text {tabel }}$ sebsar 2.028 dan nilai signifikan sebesar 0,016 nilai ini lebih kecil dari 0,05 sehingga dapat disimpulkan bahwa profesionalisme terdapat pengaruh yang negative dan signifikan terhadap kinerja guru dengan demikian hipotesis pertama sebahagian diterima.

Variabel komitmen organisasional $\left(\mathrm{X}_{2}\right)$ berpengaruh negative dan signifikan terhadap kinerja guru (Y) pada SMK Kartika XX-1 Makassar. Hal ini ditunjukkan pada tabel 4.19 nilai komitmen organisasional pada kolom $t_{\text {hitung }}$ sebesar -2.223 dimana nilai ini lebih kecil dari nilai $t_{\text {tabel }}$ sebesar 2.028 dan nilai signifikan sebesar 0,033 nilai ini lebih kecil dari 0,05 sehingga dapat disimpulkan bahwa komitmen organisasional terdapat pengaruh yang negative dan signifikan terhadap kinerja guru dengan demikian hipotesis kedua sebahagian diterima.

Variabel profesionalisme merupakan variabel yang paling dominan pengaruhnya terhadap kinerja guru pada SMK Kartika XX-1 Makassar, karena nilai koefisienprofesionalisme $\left(\mathrm{X}_{1}\right)$ sebesar $23,30 \%>$ dibandingkan nilai koefisien komitmen organisasional $\left(\mathrm{X}_{2}\right) \mathbf{1 9 . 7 0 \%}$ dengan demikian hipotesis ketiga ditolak.

Untuk mengoptimalkan kinerja guru. Kepala sekolah harus memperhatikan profesionalisme karena rendahnya kemampuan guru yang kurang stabil dan sikap dewasa tidak mampu di tampilkan secara terus menerus didepan peserta didikgunamenigkatkankinerja .Selain profesionalisme, komitmen organisasional pula sangat mempengaruhi guru dalam bekerja oleh karna itu pihak ketua yayasan harus memperhatikan finansial agar guru tersebut tetap bertahan diorganisasi

Untuk peneliti selanjutnya. Diharapkan dalam menelitikiranya memasukkan variabel-variabel lain diluar profesionalisme dan komitmen organisasional agar memperoleh hasil yang viriatif yang dapat berpengaruh terhadap kinerja guru.

\section{Referensi}

Ahmad, K. (2009). Penelitian Tindakan Kelas. Jurnal Pendidikan Penabur, 8(12), 5056.

Alfianto, S., \& Suryandari, D. (2015). Pengaruh Profesionalisme, Komitmen Organisasi Dan Struktur Audit Terhadap Kinerja Auditor. Accounting Analysis Journal, 4(1).

Astuti, I. (2012). Profesionalime Guru Sekolah Dasar. Jurnal Visi Ilmu Pendidikan, $1(2)$

Brahmasari, I. A., \& Suprayetno, A. (2009). Pengaruh Motivasi Kerja, Kepemimpinan Dan Budaya Organisasi Terhadap Kepuasan Kerja Karyawan Serta Dampaknya Pada Kinerja Perusahaan (Studi Kasus Pada PT. Pei Hai International Wiratama Indonesia). Jurnal Manajemen dan kewirausahaan, 10(2), pp-124.

Devi, E. K. D. (2009). Analisis Pengaruh Kepuasan Kerja Dan Motivasi Terhadap Kinerja Karyawan Dengan Komitmen Organisasional Sebagai Variabel

Authors : Ismail \& Herman Sjahruddin. Issue 1 (Agustus, 2018); 99 112 


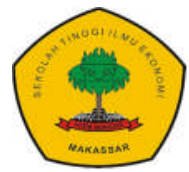

\section{JURNAL ORGANISASI DAN MANAJEMEN}

Issue 1 (Agustus, 2018)

https://doi.org/10.31227/osf.io/qt8w7

Intervening (Studi Pada Karyawan Outsourcing PT SEMERU KARYA BUANA Semarang)

Dewi, A. R. S., Hasniaty, S. E., \& Si, M. (2018). Pengaruh Gaya Kepemimpinan, Budaya Organisasi dan Komitmen Organisasi Terhadap Kinerja Pegawai Dinas Pertanian Kabupaten Mamuju. Jurnal Bisnis, Manajemen, dan Informatika, $14(2)$.

Dhanawaty, N. M. (2017). Perlunya Pembelajaran Bahasa Bali Yang Rekreatif Di Sekolah Dasar Multikultural Dan Multilingual. Madah Jurnal Bahasa dan Sastra, 4(2), 120-130.

Evendi, D. (2015). Somatotype Pemain Bola Basket dan Bola Voli Unit Kegiatan Mahasiswa UNY Tahun Pelatihan 2014/2015 (Doctoral dissertation, Fakultas Ilmu Keolahragaan).

Fujianti, L. (2012). Pengaruh Profesionalisme Terhadap Komitmen Organisasi dan Kepuasan Kerja serta Dampaknya Terhadap Kinerja Akuntan Pendidik. In Prosiding Seminar Nasional Forum Bisnis \& Keuangan I

Gunawan, I. (2013). Metode Penelitian Kualitatif. Jakarta: Bumi Aksara.

Indarjanti, P., \& Bodroastuti, T. (2012). Pengaruh Kemampuan, Usaha Dan Dukungan Organisasi Terhadap Kinerja. Jurnal Kajian Akuntansi dan Bisnis, 1(1).(1)

Islamiyah, N. Perbedaan Minat Menjadi Guru Ditinjau Dari Jenis Kelamin Dan Pekerjaan Orang Tua Pada Siswa Kelas XI SMA Negeri 2 Surakarta Tahun Ajaran 2009/2010.

Muliari, N. K., \& Setiawan, P. E. (2011). Pengaruh Persepsi Tentang Sanksi Perpajakan Dan Kesadaran Wajib Pajak Pada Kepatuhan Pelaporan Wajib Pajak Orang Pribadi Di Kantor Pelayanan Pajak Pratama Denpasar Timur. Jurnal Ilmiah Akuntansi dan Bisnis. 6(1), 1-23

Murty, W. A., \& Hudiwinarsih, G. (2012). Pengaruh Kompensasi, Motivasi Dan Komitmen Organisasional Terhadap Kinerja Karyawan Bagian Akuntansi (Studi Kasus Pada Perusahaan Manufaktur Di Surabaya). The Indonesian Accounting Review, 2(02), 215-228

Ningsih, N. (2013). Hambatan Guru Pendidikan Kewarganegaraan dalam Pelaksanaan Evaluasi Pembelajaran di SMAN 1 Sanden. Jurnal Citizenship, $1(2)$.

Nongkeng, H. (2012). Pengaruh Pemberdayaan, Komitmen Organisasional terhadap Kinerja dan Kepuasan Kerja Dosen (Persepsi Dosen Dipekerjakan PTS Kopertis Wilayah IX Sulawesi di Makassar). Jurnal Aplikasi Manajemen, 10(3),

Posuma, C. O. (2013). Kompetensi, Kompensasi, Dan Kepemimpinan Pengaruhnya Terhadap Kinerja Karyawan Pada Rumah Sakit Ratumbuysang Manado. Jurnal EMBA: Jurnal Riset Ekonomi, Manajemen, Bisnis dan Akuntansi, 1(4).

Puspitawati, N. M. D. (2013). Kepuasan Kerja Dan Komitmen Organisasional: Pengaruhnya Terhadap Kualitas Layanan Hotel Bali Hyatt Sanur. Program Studi Manajemen, Program Pascasarjana, Universitas Udayana Denpasar.

Ramadika, A. P., Nasir, A., \& Wiguna, M. (2014). Pengaruh Role Stress, Gender, Struktur Audit Dan Profesionalisme Terhadap Kinerja Auditor Bpk-Ri Perwakilan Provinsi Riau. Jurnal Online Mahasiswa (JOM) Bidang Ilmu Ekonomi, 1(2), 1

Revita, M. (2015). Pengaruh Kompetensi, Disiplin Kerja Dan Lingkungan Kerja Terhadap Kinerja Pegawai Pada Dinas Energi Dan Sumber Daya Mineral Kabupaten Sigi. Katalogis, 3(9), 159-170.

Halaman 111

Authors : Ismail \& Herman Sjahruddin. Issue 1 (Agustus, 2018); 99 112 


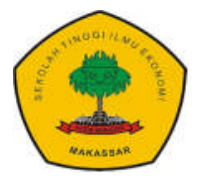

JURNAL ORGANISASI DAN MANAJEMEN

Issue 1 (Agustus, 2018)

https://doi.org/10.31227/osf.io/qt8w7

Sari, R. N., \& Sjahruddin, H. (2018). Pengaruh Kompetensi Terhadap Kinerja Dimoderasi Profesionalisme Karyawan.

Sugiyono. (2012). Metode Penelitian Kuantitatif Kualitatif dan R\&D. Bandung: Alfabeta.

Sugiyono. (2013). Metode Penelitian Kuantitatif, Kualitatif dan R\&D. Bandung: Alfabeta.

Sumarsih, S. (2017). Pengaruh Motivasi Kerja Dan Kompetensi Profesionalterhadap Kinerja Guru Sekolah Dasar Di Kecamatan Cikarang Utara, Kabupaten Bekasi. JURNAL PENDIDIKAN DASAR, 7(2), 361-374.

Sutrisno, Edy. 2009. Manajemen Sumber Daya Manusia. Edisi Pertama. Jakarta: Kencana Prenada Media Group

Syahruddin, Herman, Dkk. (2017). Modul Pengolahan Data. Makassar : Sekolah Tinggi Ilmu Ekonomi Makassar .

Tranggono, R. P., \& Kartika, A. (2008). Pengaruh Komitmen Organisasional dan Profesional Terhadap Kepuasan Kerja Auditor Dengan Motivasi Sebagai Variabel Intervening (Studi Empiris pada Kantor Akuntan Publik di Semarang). Jurnal Bisnis dan Ekonomi, 15(1).

Wajdi, M. B. N., Ali, M., \& Lestari, V. N. S. (2017). Definisi Dan Karakteristik Makalah.

Widodo, T. (2012). Pengaruh Lingkungan Kerja, Budaya Organisasi, Kepemimpinan Terhadap Kinerja (Studi Pada Pegawai Kecamatan Sidorejo Kota Salatiga). Jurnal Ilmiah Among Makarti, 3(5).

Yogaswara, A., Fattah, N., \& Sa'ud, U. S. (2010). Kontribusi Manajerial Kepala Sekolah Dan Sistem Informasi Kepegawaian Terhadap Kinerja Mengajar Guru. Jurnal Penelitian Pendidikan, 11(2), 60-72.

Yulianti, L., Sjahruddin, H., \& Tahir, B. (2017). Implementasi Customer Relationship Management (CRM) Terhadap Kepuasan dan Loyalitas Pelanggan Pengguna Smartphone Android Merek Samsung.

Zaeni, A., Abdullah, G., \& Egar, N. (2017). Pengaruh Kompetensi Pedagogik Guru Dan Sertifikasi Guru Terhadap Kinerja Guru Sd/Mi Di Kecamatan Petarukan Kabupaten Pemalang. Jurnal Manajemen Pendidikan (JMP), 5(2).

Zakaria, R. (2016). Efektivitas Pembinaan Kompetensi Profesional Tenaga Pendidik di SMAN 10 Kota Tangerang Selatan (Bachelor's thesis, Jakarta: FITK UIN Jakarta).

Authors : Ismail \& Herman Sjahruddin. Issue 1 (Agustus, 2018); 99 112 